Review

\title{
The Role of Nicotinamide Adenine Dinucleotide Phosphate Oxidases in Lung Architecture Remodeling
}

\author{
Anantha Harijith ${ }^{1}$, Viswanathan Natarajan ${ }^{2,3}$ and Panfeng Fu ${ }^{3, *}$ \\ 1 Department of Pediatric, University of Illinois at Chicago, Chicago, IL 60612, USA; harijith@uic.edu \\ Department of Medicine, University of Illinois at Chicago, Chicago, IL 60612, USA; visnatar@uic.edu \\ 3 Department of Pharmacology, University of Illinois at Chicago, Chicago, IL 60612, USA \\ * Correspondence: pfu@uic.edu; Tel.: +1-312-355-5893
}

Received: 13 November 2017; Accepted: 14 December 2017; Published: 19 December 2017

\begin{abstract}
Chronic lung disorders, such as pulmonary artery hypertension (PAH), chronic obstructive pulmonary disease (COPD), asthma and neonatal bronchopulmonary dysplasia (BPD), are characterized by airway and/or vascular remodeling. Despite differences in the pathology, reactive oxygen species (ROS) have been highlighted as a critical contributor to the initiation and development of airway and vascular remodeling. Nicotinamide adenine dinucleotide phosphate (NADPH) oxidases (Nox) appear to play a pivotal role in lung signaling, leading to marked changes in pulmonary airway and vascular cell phenotypes, including proliferation, hypertrophy and apoptosis. In this review, we summarized the current literature regarding the role of Nox in the airway and vascular remodeling.
\end{abstract}

Keywords: NADPH oxidase; remodeling; PAH; COPD; asthma; BPD

\section{Introduction}

The lung tissue consists primarily of airway and vasculature structures. Both structures undergo remodeling under certain disease conditions, such as asthma, chronic obstructive pulmonary disease (COPD), neonatal bronchopulmonary dysplasia (BPD) and pulmonary artery hypertension (PAH) [1-3]. Despite differences in the causal agents, these diseases exhibit various degrees of inflammatory changes, airway and vascular structural alterations. Airway and vascular remodeling may be defined as a process of sustained disruption and modification of structural cells and tissues leading to the development of a new airway or vascular structure and consequent new functions. Reactive oxygen species (ROS) are intracellular chemical species that are reactive toward lipids, proteins and DNA. They have been implicated in the pathophysiology of a variety of lung diseases including asthma, COPD, BPD and PAH [4-6]. Accumulating evidence has highlighted the importance of Nicotinamide adenine dinucleotide phosphate (NADPH) oxidases in airway and pulmonary vasculature remodeling. The NADPH oxidase family is composed of 7 catalytic subunits termed Nicotinamide adenine dinucleotide phosphate oxidases (Nox) 1-5 and dual oxidase 1 (Duox1) and Duox2, regulatory subunits p22phox, p47phox, Noxo1, p67phox, Noxa1, p40phox and the major binding partner Rac. Nox proteins produce superoxide $\left(\mathrm{O}_{2}{ }^{-}\right)$via a single electron reduction. Superoxide is highly reactive and short lived. Superoxide can dismutate to hydrogen peroxide $\left(\mathrm{H}_{2} \mathrm{O}_{2}\right)$, spontaneously or enzymatically via superoxide dismutase (SOD). Although production of $\mathrm{O}_{2}{ }^{-}$is the main biological function of Nox proteins, much of the signaling that occurs is directly mediated by its dismutation product $\mathrm{H}_{2} \mathrm{O}_{2}$. This is due to the facts that $\mathrm{H}_{2} \mathrm{O}_{2}$ is more stable than $\mathrm{O}_{2}{ }^{-}$and is capable of crossing biological membranes. The lung expresses most NADPH oxidases with preferential expression of Nox1 in epithelial and endothelial cells, Nox2 in alveolar macrophages and endothelial cells, Nox4 in smooth 
muscle cells, fibroblasts and endothelial cells, Duox1/2 in bronchial epithelial cells (reference Table 1). As professional enzymes generating ROS, NADPH oxidases are commonly considered the major source of oxidative stress during acute or chronic inflammation. However, these enzymes have been shown to be involved in a broad range of physiological processes and ROS are increasingly appreciated as critical mediators in a broad range of cellular processes, such as cell proliferation, migration, differentiation, immunomodulation and oxygen sensing [7-10]. This review will focus on the involvement of NADPH oxidase family in the diseases of asthma, COPD, BPD and PAH with emphasis on pulmonary airway and vascular remodeling.

Table 1. Lung tissue distribution of Nox proteins.

\begin{tabular}{cl}
\hline Type of Nox & \multicolumn{1}{c}{ Cell Type Where Found } \\
\hline Nox1 & Smooth muscle, endothelium, upper airway epithelium \\
\hline Nox2 & $\begin{array}{l}\text { Inflammatory cells (macrophage and neutrophils), mesenchymal cells, smooth muscle, } \\
\text { endothelium, upper and lower airway epithelium }\end{array}$ \\
\hline Nox3 & Inducible in lung endothelium \\
\hline Nox4 & $\begin{array}{l}\text { Inflammatory cells (macrophage and neutrophils, mesenchymal cells, smooth muscle, } \\
\text { endothelium, lower airway epithelial cells }\end{array}$ \\
\hline Nox5 & Smooth muscle, endothelium \\
\hline Duox1 & Upper airway epithelium \\
\hline Duox2 & Upper airway epithelium \\
\hline & Nox: Nicotinamide adenine dinucleotide phosphate oxidases; Duox: Dual oxidase.
\end{tabular}

\section{Pulmonary Airway and Vascular Remodeling}

Lung airway remodeling, a result of chronic and acute inflammation and injury, consists of aspects of airway remodeling and vascular remodeling. Airway remodeling is the results of various cellular and extracellular matrix (ECM) pathological changes, including the changes occurring in airway epithelium, smooth muscle cells, ECM composition and immune cells. Airway epithelia injury and abnormalities in repair are the most likely causes of remodeling [11]. Repeated epithelial injury observed in chronic asthma is associated with release of proinflammatory cytokines and multiple growth factors leading to permanent changes in airway wall morphology [12]. Cigarette smoke is the major cause of COPD. Repetitive exposure of epithelium to this noxious agent leads to marked structural changes to the epithelium with thickening and squamous metaplasia accompanied by elevated mesenchymal responses. Among various growth factors related to airway remodeling, epidermal growth factor (EGF) and transforming growth factor $\alpha$ (TGF- $\alpha$ ) play essential roles in airway remodeling. Activation of the EGF receptor promotes both migration and proliferation of epithelial cells [13]. However, EGF signaling is not appropriately activated by the repairing epithelium in asthma [14]. In COPD, cigarette smoke enhanced EGF receptor expression in airways epithelium [15] and elevated expression of both EGF and TGF- $\beta$ [16]. Thus, the imbalance between proliferative and anti-proliferative signaling represents an important mechanism of airway remodeling.

The pulmonary circulation is a highly specialized vascular bed that physically and functionally connects the heart and the lung. Pulmonary vascular remodeling leads to increased pulmonary vascular resistance and reduced compliance, which play important pathological roles in the development of a variety of pulmonary diseases including COPD, PAH, BPD and asthma [17]. Pulmonary vascular remodeling is the consequence of a wide variety of stimuli exerting on the different components of a blood vessel. Histologically, pulmonary vascular remodeling is characterized by thickening of all three layers of the blood vessel, namely, the adventitia, the media and the intima. Pulmonary vascular remodeling is the result of a wide variety of stimuli, both physical and chemical. These stimuli include mechanical stimuli [18,19], hypoxia [20], growth factors [21,22] and inflammatory cytokines [23]. 
ROS have been identified to involve all above mentioned stimuli by influencing intracellular signaling pathways activated for vascular remodeling [24-27]. Pro-inflammatory factors involved in lung remodeling are a major aspect regulated by Nox-derived ROS. It has been shown that lung cells release inflammatory mediators and cytokines/chemokines, such interleukine- $1 \beta$ (IL-1 $\beta$ ), interleukine- 6 (IL-6), interleukine-8 (IL-8) and tumor necrosis factor- $\alpha$ (TNF- $\alpha$ ) in response to oxidative stress through the activation of redox-sensitive transcription factors including hypoxia-inducible factor 1 (HIF-1), nuclear factor-kappa B (NF-kB) [28-33].

\section{NADPH Oxidases and PAH}

PAH is characterized by vascular remodeling and upregulated vasoconstriction. Increased pulmonary arterial pressure due to decreased arterial lumen leads to right ventricular failure and death [34]. Accumulating evidence indicates implication of ROS in the pathogenesis of PAH [35] (reference Figure 1). Hyperoxia increased Nox1 expression in mouse lung cell lines and Nox1-deficient mice showed attenuated lung injury induced by hyperoxia [36]. Moreover, Nox1 is increased in neonatal mice with PAH after hyperoxia [37] and in neonatal piglets exposed to hypoxia [38]. Nox1 may be involved in pulmonary vascular remodeling in monocrotaline-treated rats [39]. Consistent to this study, another study showed that monocrotaline induced Nox1 expression and eukaryotic elongation factor 2 kinase (eEF2K) inhibitor, A-484954 attenuated pulmonary artery hypertrophy and fibrosis through inhibition of Nox1 [40]. Nox1 can also be induced by estrogen metabolite, $16 \alpha$-hydroxyestrone $(16 \alpha \mathrm{OHE})$ in human pulmonary artery smooth muscle cells (PASMCs). Estrogen, through estrogen receptor- $\alpha$, increases Nox1-derived ROS in PASMCs. $16 \alpha \mathrm{OHE}$ stimulated transient ROS production and increased Nox1 expression. Nox $1^{-/-}$but not Nox4 $4^{-/-}$mice were protected against PAH and vascular remodeling [41]. One of the early events contributing to the pathophysiology of PAH is endothelial dysfunction [34]. Evidence from endothelial cells support implication of Nox1 in PAH as well. In human pulmonary artery endothelial cells (HPAECs), hypoxia induced Nox1 expression, assembly and oxidase activity leading to elevation in sonic hedgehog and Grem1 expression. Loss of either Nox1, sonic hedgehog or Grem1 attenuates hypoxia-induced HPAECs proliferation [42]. However, there is evidence that is opposite to the findings above. Deficiency of Nox1 leads to reduced number of apoptotic PASMCs, which is implicated in the hypertrophy of pulmonary vessels. Interestingly, deficiency of Nox1 results in a decrease in a voltage-dependent $\mathrm{K}^{+}$channel, Kv1.5 protein and an increase in intracellular potassium levels, indicating a critical role for Nox1 in cellular apoptosis by regulating Kv1.5 and intracellular potassium levels [43].

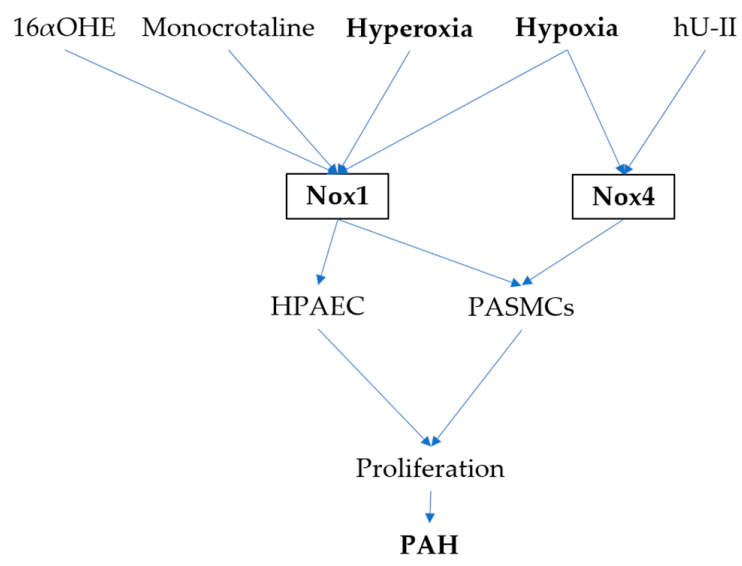

Figure 1. Role of Nox in pulmonary artery hypertension (PAH). Nox1 and Nox4 expressed in human pulmonary artery endothelial cells (HPAECs) and pulmonary artery smooth muscle cells (PASMCs) are activated by various stimuli, among which hyperoxia and hypoxia are the most important ones. reactive oxygen species (ROS) generated by Nicotinamide adenine dinucleotide phosphate oxidases 1 (Nox1) and Nox4 stimulate cell proliferation, which is the major mechanism for PAH. 
As the first identified NADPH oxidase, Nox2 is well known for its expression in phagocytic cells as major defense mechanism against bacterial infection, however it is also expressed in cells comprising the vascular wall and is activated by pathways like Nox1. Upon activation, it binds to subunits of p22phox, p47phox, p67phox and Rac1 at the plasma membrane. There is evidence that Nox2 is associated with vasosonstriction and elevated Nox2 correlates with impaired pulmonary vasorelaxation in both lamb and piglet models of neonatal PAH [44,45]. The role of Nox2 in PAH was intensively investigated. It was appreciated that hypoxia-induced PAH was blocked in Nox2 knockout mice $[35,46]$, revealing a pivotal role for Nox2 in the pathogenesis of hypoxic PAH. However, Nox2 mRNA has not been found to be changed in the lung of mice exposed to hypoxia [47]. In contrast, hypoxia induced Nox 2 mRNA and protein levels significant upregulation in pulmonary arteries and endothelial progenitor cells of Sprague-Dawley rat concomitant with remodeling in pulmonary arteries and right ventricle [48,49]. In addition, the Nox2 inhibitor apocynin improves oxygenation and decreases ROS in persistent pulmonary hypertension newborn (PPHN) lambs [46].

Originally identified in the kidney, Nox4 is believed to be constitutively active and its regulation is through its expression. Expression levels of Nox4 were reported to be as much as 100-fold greater than other isoforms in vascular smooth muscle cells. Nox4 has been intensively investigated in tumor growth factor (TGF) signaling pathways. TGF upregulates Nox4 expression in various cell types, including PASMCs [50-52], airway epithelial cells [53], airway smooth muscle cells [51], artery smooth muscle cells [54] and myofibroblast cells [55]. Meanwhile, TGF plays important role in PAH [56-59]. In a hypoxia-induced PAH model, Nox4 mRNA was exclusively up-regulated in the lung tissue and Nox4 was identified to be expressed in the media of small pulmonary arteries, with increased labeling intensities after chronic exposure to hypoxia [47]. In PASMCs, Nox4 was localized primarily to the perinuclear space and its expression levels were increased after exposure to hypoxia $[47,60]$. Hypoxia-induced Nox4 production is through the autocrine pattern of TGF- $\beta 1$ from PASMCs. In this scenario, exposure of PASMCs to hypoxia leads to TGF- $\beta 1$ production, which in turn stimulates Nox 4 expression in a Smad dependent manner [52]. Hypoxia may also regulate Nox4 expression through $\mathrm{NF}-\mathrm{Kb}$ [61]. Idiopathic pulmonary arterial hypertension (IPAH) patients have 2.5-fold increase in Nox4 expression, which was localized in the vessel media [47,62]. Human urotensin (hU-II) is a potent vasoactive peptide possibly involved in PAH. It has been shown that hU-II upregulated expression of Nox4 and p22phox in PASMCs and stimulated PASMCs proliferation in a ROS dependent manner and Nox4 activation resulted in mitogen-activated protein kinase p38, extracellular signal-regulated kinases 1/2 (Erk1/2) and protein kinase B (Akt) activation, which subsequently enhanced plasminogen activator inhibitor-1 (PAI-1) expression and increased proliferation of PASMCs [50]. Nox4 may also contribute to PASMCs proliferation through cyclin D1, which regulates the transition from G0/G1 to S phase in the cell cycle, resulting in the activation of genes that are necessary for cell-cycle progression. Cyclin D1 was observed to increase in PPHN lungs and PASMC [46] and PASMCs isolated from monocrotaline-treated rats [39]. Inhibition of Nox4 by small interfering RNA decreased cyclin D1 expression in PPHN PASMC, indicating Nox4 regulates PASMCs proliferation through cyclin D1. These results support an important role for Nox4 in PAH through regulating vascular remodeling.

Nox proteins' cofactor p47 might also play roles in PAH. P47 has been shown to mediate ROS in human lung microvascular endothelial cells (HLMVECs) in response to hepatic growth factor (HGF) [63]. A recent study showed that hyperoxia induced sphingosine kinase 1 (SphK1)-dependent sphingosine-1-phosphate (S1P) accumulation in HLMVECs. S1P in turn stimulated p47 translocate to cell periphery and ROS generation [64]. In another report, SphK1/S1P axis was shown to promote PASMCs proliferation [65]. Therefore, it is possible that the proliferative effect of SphK1/S1P observed in PASMCs is mediated by p47-dependent ROS.

\section{NADPH Oxidases and COPD}

COPD is characterized by inflammation in small airways and lung parenchyma and resultant airway destruction with progressive, irreversible airflow restriction. The complex pathology of 
COPD involves distinct cellular responses of different regions of the respiratory tract to stimuli, especially cigarette smoke. Among various factors, TGF, EGF receptor, matrix metalloprotease (MMP) and inflammatory mediators, oxidative stress appears to play important roles in the pathology of COPD. There is clear evidence of oxidative stress in COPD patients compared with non-smoking controls [66-69]. $\mathrm{H}_{2} \mathrm{O}_{2}$ levels in the exhaled breath condensate of COPD patients were much higher than that of healthy controls. Even the levels of $\mathrm{H}_{2} \mathrm{O}_{2}$ were associated with the severity of the disease [67]. Other biomarkers that represent oxidative stress were identified to be increased in COPD as well. For example, isoprostanes, the oxidized products of arachidonic acid, were found in exhaled breath condensate of COPD patients [68]. Malondialdehyde (MDA), a product of fatty acid peroxidation, was significantly higher in exhaled breath condensate of COPD patients than healthy controls. Meanwhile, serum levels of MDA were found to correlate with COPD severity [70]. ROS can be generated in multiple types of cell, which are implicated in COPD.

In COPD, smooth muscle in the small airways exhibit hyper responsiveness and higher contractility, which contribute to airway remodeling and thickening. Increased airway smooth muscle mass is related to the severity of COPD [71]. Given the fact that oxidative stress and oxidative damage play a pivotal role in the pathogenesis of COPD [72], Nox proteins expressed in airway smooth muscle cells may play important role in COPD. Indeed, airway smooth muscle cells express Nox4 [51,73-75], p22 [76] and p67 [77]. As the predominant Nox in airway smooth muscle cells, Nox4 has been shown to be upregulated in airway smooth muscle cells of COPD patients [74] and correlate to the severity of COPD [71].

The airway epithelium is one of the first targets of environmental factors implicated in the pathogenesis of COPD and is likely to have impacts upon COPD progression, while there is little evidence of abnormal ROS production from the epithelium. Nevertheless, few studies still revealed the implication of airway epithelial Nox proteins in COPD. Cigarette smoke induced Nox activity through kinin B1 receptor in human alveolar epithelial cells [78]. Nox1, Duox1, Duox2 and DuoxA2 were upregulated in isolated tracheobronchial epithelial cells from COPD patients [79]. Other study showed that expression of Duox1 in the airway brushed tracheal and bronchial epithelium of smoker was significantly downregulated, whereas Duox2 was upregulated [80]. Although these studies didn't show many mechanisms of how Nox proteins from airway contribute to the pathology of COPS, they still provided evidence that ROS derived from Nox proteins might represent certain aspects of the pathology of COPD.

COPD is characterized by airway narrowing, which is determined by alteration of extracellular matrix (ECM) protein components [81]. ECM is a protein network mainly composed of compliant elastin fibers, collagens, fibronectin, tenascin and proteoglycans, all secreted and organized by the cells embedded with this matrix. The obvious changes in ECM relevant to COPD are reductions in the expression or functional organization of elastic fibers and proteoglycans in the airways and parenchyma $[82,83]$. Fibrosis of the small airways with increased expression of tenascin-C, fibronectin and possibly collagens in patients with mild to moderate COPD can be observed. Oxidation of ECM proteins has emerged as important mechanism of ECM alteration relevant to COPD and fibrosis. TGF- $\beta$ appears to be a prominent factor capable of stimulating ECM production. Like what was discussed in the PAH, many pro-fibrotic effects of TGF- $\beta$ are dependent on Nox4. Inhibition of Nox4 suppressed TGF- $\beta$-induced expression of fibronectin, collagen I, $\alpha$-smooth muscle actin [84]. Similar observations were noted in fetal lung mesenchymal cells and pulmonary fibroblast cells. ROS can lead to carbohydrate oxidation on glycosaminoglycans yielding $\alpha$-hydroxyalkyl radicals capable of catalyzing reactions with nearby $\mathrm{C}-\mathrm{OH}$ and $\mathrm{C}-\mathrm{OR}$ bonds, resulting in the oxidation of collagens, elastin, fibronectin, laminin and glycosaminoglycans [85]. Oxidation of ECM leads to destabilization of interactions between ECM components and growth factors. Oxidation of perlecan leads to proteolysis of fibroblast growth factor 2 (FGF2), which binds to perlecan via its heparin sulfates. Collagen III is a homotrimer linked each other by three disulfide bridges, which are important for maintaining the 
folding and stability of the molecule [86]. There is an important auto-antigen recognition mechanism for in collagen $\mathrm{V}$, which is implicated in the pathogenesis of fibrosis [87].

As part of COPD, emphysema is characterized by small airway inflammation and airspace enlargement due to lung alveolar destruction [88]. In human emphysematous lungs, the number of Nox2-positive cells was elevated, whereas increased Nox2 and Nox1 mRNA expression was noted in mouse emphysematous lungs. Nox 2 but not Nox1-deficient mice were protective against elastase-induced alveolar enlargement. The site of Nox2 exerted its effects was demonstrated at alveolar macrophage [89]. Compared to non-smokers, COPD patients exhibit higher neutrophil count in both bronchial alveolar lavage and in the sputum [90] and neutrophil from COPD patients appeared to be more effective in producing ROS [91], which is believed to be generated by Nox2. Excessive ROS in leukocytes enhanced inflammation through NF-kB-mediated transcription of inflammatory mediators [92]. Activation of Nox2 in leukocytes was mediated by Mac-1, which is an inegrin molecule expressed in neutrophils and this molecule is involved in neutrophil emigration and recruitment and adhesion of neutrophils to the endothelium. COPD patients exhibit significant upregulation of Mac-1 [91]. Phosphorylation of Mac-1 leads to Nox activation and the crosslinking of Mac-1 induces ROS burst in neutrophil [93-95].

Toll like receptors (TLRs) are well known for their ability to recognize microbiology. The infection unrelated roles for TLRs has newly emerged [96-98]. TLR4 deficiency mice has been shown to exhibit emphysema as they aged [99]. The underlying mechanism of this observation is that Nox3 was upregulated in the lungs and endothelial cells of TLR4 deficiency mice, resulting in increased oxidant generation and elastolytic activity. However, other Nox proteins may play controversial roles to Nox3. One study revealed that Nox 2 and p47 knockout mice were more susceptible to cigarette smoke-induced inflammatory response and airspace enlargement. This was associated with enhanced activation of TLR4-NF-kB pathway [100].

\section{NADPH Oxidases and Asthma}

Asthma is a chronic inflammatory disease of the airways, characterized by remodeling of the airway leading to enhanced airway hyper responsiveness and increased mucus secretion and changes in the airway vasculature associated with remodeling of the airway and excessive airway narrowing [101,102]. Airway remodeling of asthma is characterized by subepithelial fibrosis and smooth muscle hyperplasia, which are mediated by cytokines, such as TGF- $\beta$ [103], EGF [104] and periostin [105]. Accumulating evidence appreciates implication of ROS in the extent of ongoing inflammation and the severity of asthma [106-108] (reference Figure 2).

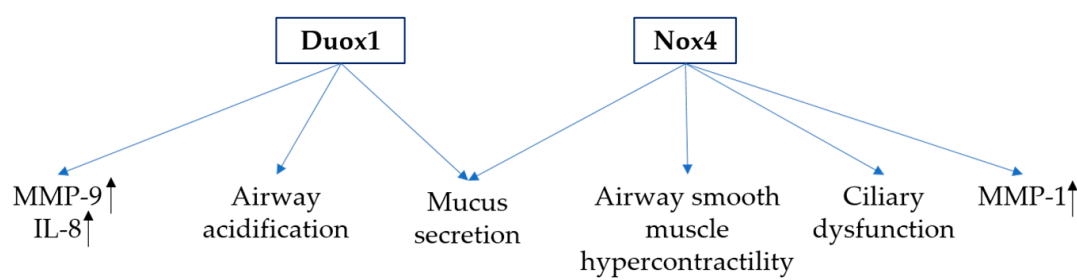

muscle
hypercontractility

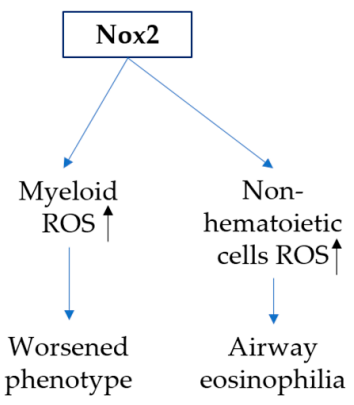

Figure 2. Role of Nox in asthma. Nox2, Nox4 and dual oxidase 1 (Duox1) play critical roles in asthma through various mechanisms. Both Duox1 and Nox4 stimulate mucus secretion and matrix metalloprotease (MMP) production in airway epithelial cells. In addition, Nuox1 enhances airway acidification and Nox4 induces ciliary dysfunction and airway smooth muscle hypercontractility. Nox2 plays distinctive roles in asthma. Nox2 expressed in myeloid and non-hematoietic cells plays distinctive roles in asthma. Nox2 expressed in myeloid cells is believed to mediate the worsened phenotype of asthma, while Nox2 expressed in the lung structure cells mediates airway eosinophilia. 
Duox exist as two isoforms, of which Duox1 is primarily expressed in the tracheobronchial epithelium, whereas Duox2 has been detected in salivary or submucosal glands [109-111]. In addition to postulated roles in airway host defense, recent studies have suggested alternative functions of airway epithelial Duox1 in mediating asthma. Mucous metaplasia and airway remodeling as hallmarks of allergic asthma have been associated with expression and activation of epidermal growth factor receptor (EGFR) signaling [112]. Constitutive EGFR activation has been associated with cysteine oxidation, which was diminished by pharmacologic or genetic inhibition of the epithelial Duox1 [113]. Targeted inhibition of airway Duox1 in mice reversed symptoms of asthma [113]. Meanwhile, Duox1 regulated mucus secretion through mediating TNF-alpha-converting enzyme (TACE) cleavage into soluble TGF- $\alpha$, which mediates mucin expression [114]. Other mechanisms of Duox1 regulation of asthma include enhanced inflammatory mediators including IL-8 or matrix metalloprotease-9 (MMP-9) [12,115] and increased airway acidification [116].

In addition to the role of Duox in asthma, Nox4 was also identified to express along with Duox1 and Duox 2 in bronchial biopsy specimens by using microarray [75]. Increased Nox4 appeared to associate with airway smooth muscle hypercontractility, which was abrogated by genetic inhibition of Nox4 by small interfering RNA and pharmacological inhibition [75]. Bronchial epithelial ciliary dysfunction was observed in neutrophilic asthma but not in nonneutrophilic asthma. Nox4 and Duox1 were both elevated and Duox2 was elevated in nonneutrophilic asthma. Pharmacologic inhibition of Nox4 improved ciliary function in ex vivo epithelial strips and abolished ciliary abolished ciliary dysfunction in the murine asthma model with no reduction in inflammation [117]. Moreover, Nox4 was identified to contribute to regulating epithelial signaling pathways that promote the production of mucin 5AC (MUC5AC) or matrix metalloprotease (MMP)-1 [118,119]. In normal human nasal epithelial (NHNE) cells Nox4 was the only Nox protein up-regulated by exogenous $\mathrm{H}_{2} \mathrm{O}_{2}$ stimulation. Nox4 was responsible for the increased oxidative stress in NHNE and contributed to the increase in MUC5AC production. Same effects of Nox4 were observed in human lung mucoepidermoid carcinoma cell line NCI-H292 cells as well. Erk kinase seems to mediate Nox4 induction in NHNE cells by exogenous $\mathrm{H}_{2} \mathrm{O}_{2}$. However, Erk kinase may be regulated by Nox4 in alveolar epithelial cell line A549, suggesting a reciprocal regulation mechanism between Nox4 and Erk kinase [118]. Diesel exhaust particles (DEP) induced MMP-1 production in a Nox4-dependent manner. Inhibition of Nox4 abolished DEP-induced ROS production, MMP-1 mRNA expression and Erk phosphorylation [118].

Eosinophils and neutrophils, both of which express Nox2, perhaps the major source of ROS during allergic inflammation. Eosinophils play pivotal roles in the pathophysiology of asthma and exacerbations [120,121]. It is believed that ROS production by these myeloid cells contributes to asthma development. As early responders and regulator of innate and adaptive immune responses during allergic inflammation, eosinophils might also take advantage of Nox2-dependent pro-inflammatory signaling, although this possibility has not yet been tested. On the contrary, Nox2 might negatively regulate acute allergic reactions through the cross-talk between T-lymphocytes and macrophages to limit the inflammatory response [122]. Accordingly, Nox2 deficiency resulted in enhanced recruitment of inflammatory cells to the airways and cytokine production, which worsens the asthmatic phenotype compared with wild type mice [123]. Nevertheless, there is evidence indicating a role for Nox2 within structural cell types rather than inflammatory cells contributes to asthma. This study took advantage of chimera of Nox2-deficiency mice, in which Nox2 was absent only in non-hematopoietic cell types, which showed that only non-hematopoietic Nox 2 contributes to development of airways eosinophilia [124].

Of note, in addition to endogenous Nox, exogenous Nox also contributes to asthma. One study showed that pollen contains intrinsic Nox activity. Removal of pollen Nox activity reduced antigen-induced allergic airway inflammation [125]. 


\section{NADPH Oxidases in Neonatal BPD}

Hyperoxia induced Nox1 is an important contributor to ROS production and disruption of the alveolocapillary barrier during hyperoxia [36]. Nox1 is an upstream actor in oxidative stress-induced acute lung injury involving jun N-terminal kinase (JNK) and Erk1/2 kinase pathways in mice. Increased expression of the reactive oxygen species generating enzyme, Nox1, was noted with hyperoxic exposure in the young but not adult lung [37]. Nox1 appeared to mediate mitochondrial ROS generation in early postnatal hyperoxia-induced phenotype comparable to BPD [126], which is characterized by decreased alveolarization and increased muscularization of resistance pulmonary arteries.

Endothelial activation mediated by lipopolysaccharide (LPS) contributes to lung inflammation and alveolar remodeling seen in premature infants with BPD. Aberrant pro-inflammatory angiogenesis following endothelial dysfunction is noted in chronic inflammatory disorders [127]. It has been shown that Nox2 silencing or use of conditioned media from Nox2-silenced cells attenuated LPS mediated angiogenic responses. This demonstrates the importance of Nox2 in regulating pro-inflammatory Ang2-dependent angiogenesis. Further it has been shown that Nox2 regulates Ang2 and vascular endothelial growth factor-A (VEGF-A) expression in pulmonary endothelial cells through the IKK $\beta /$ NF- $K B$ and MAPK/AP-1 pathways [128,129]. Thus, inhibiting Ang2 using antibodies or modulating Nox2 activity could emerge as therapeutic strategies to decrease lung injury in bacterial sepsis. Studies that inhibit Nox (VAS2870) or suppress superoxide (PEG-SOD) suggest that superoxide contributes to LPS mediated induction of angiogenic markers. Data from studies support a role for Nox2-induced ROS in LPS-mediated Ang2 and VEGF-A expression.

Our data have also shown that sphingosine 1 phosphate (S1P) plays a significant role in the pathogenesis of BPD by acting through Nox2 and Nox4 [130]. Sphk1 ${ }^{-/}$neonatal mice exposed to hyperoxia showed protection against alveolar simplification compared to wild type and Sphk $2^{-/-}$ hyperoxic controls. This was accompanied by a reduction in expression of Nox 2 and Nox4. In another experiment, we noted that $\mathrm{Sphk} 1^{-/-}$juvenile mice exposed to hyperoxia showed reduced concentration of $\mathrm{H}_{2} \mathrm{O}_{2}$ in bronchial alveolar lavage (BAL) suggesting reduced production of ROS in lungs [64]. In vitro experiments using HLMVECs showed that S1P activated Nox2 by activating the p47 component. This was demonstrated under hyperoxia accompanied by increased production of S1P. P47 activation and ensuing ROS production was inhibited by SphK1 inhibitor PF-543. We further demonstrated that S1P acts through S1P receptor 1 or 2 to activate p47phox followed by production of ROS. The role of p47 in Nox2 activation was supported by a recent study [131], in which p47 was found to be phosphorylated in invariant natural killer T (iNKT) cells underwent hypoxia-reoxygenation. iNKT cells isolated from $\mathrm{p} 47^{-/-}$mice had impaired ROS generation, which is believed to be mediated by Nox2.

\section{Conclusions}

With increasing recognition of ROS as critical factors in the pathogenesis of various diseases, Nox inhibitors are the most promising therapeutic option for diseases associated with oxidative stress including lung diseases [132]. Both airway and vascular remodeling are a complex, multi-factorial processes, influenced by multiple physical and chemical stimuli. Undoubtedly, they have their own unique mechanisms but they do share some common mechanisms. For example, both vascular vessels and airway contain smooth muscle cells, which from both tissues are all sensitive to TGF stimulation and play critical roles in remodeling. In view of the complexity of remodeling, targeting Nox proteins-derived ROS might represent a promising strategy for treatment of remodeling-related lung diseases. Targeting Nox1/4 with a pharmacological inhibitor, GKT137831, attenuated hypoxia-induced pulmonary smooth muscle cell proliferation, vascular remodeling and the development of PAH [133]. The Nox inhibitor and ROS scavenger, apocynin, has been shown to reverse the hypoxia-induced decrease in $\mathrm{Kv}$ current density related to intracellular $\mathrm{Ca}^{2+}$ concentration and associated smooth muscle cells contraction [134] and airway inflammation [135]. N-acetylcysteine (NAC) as a 
precursor of grutathione (GSH) synthesis has been shown to reduce cigarette smoke-induced abnormalities in alveolar macrophages, fibroblast and epithelial cells [136-139]. Treatment with NAC in humans increased lung lavage GSH levels, decreased bronchial alveolar lavage polymorphonuclear leukocyte [140]. Administration of NAC in COPD patients reduced sputum eosinophilic cation protein concentrations and the adhesion of polymorphonuclear leukocytes [141]. Pharmacologic inhibitor against Nox4 appears to be effective as an anti-fibrotic agent in preclinical models [142]. Diverse expression of various Nox isoforms in different cell types within the bronchi, lung parenchymal cells and immune cells adds to the great complexity with respect to contributions of ROS to various lung disorders. However, our understanding of the pathophysiological roles of Nox family in the lung is still in its early stage. Advances in understanding the mechanisms of Nox family in disease pathogenesis will expedite the eventual development and test of Nox inhibitors in specific lung diseases. As Nox family has broad pathophysiological roles in different cell types within the lung, defining their pathological context is critical in designing informative preclinical and successful clinical studies. Avenues such as validation of the expression and localization of Nox isoforms within the lungs and identifying Nox proteins as biomarkers of disease progression deserve further studies.

Acknowledgments: This paper is supported by the US National Institutes of Health grant P01 HI09850 to VN.

Author Contributions: Panfeng Fu, Anantha Harijith and Viswanathan Natarajan conceived and wrote the paper.

Conflicts of Interest: The authors declare no conflict of interest.

\section{References}

1. Khan, M.A.; Assiri, A.M.; Broering, D.C. Complement mediators: Key regulators of airway tissue remodeling in asthma. J. Transl. Med. 2015, 13, 272. [CrossRef] [PubMed]

2. Al-Muhsen, S.; Johnson, J.R.; Hamid, Q. Remodeling in asthma. J. Allergy Clin. Immunol. 2011, 128, 451-462; quiz 463-454. [CrossRef] [PubMed]

3. Shimoda, L.A.; Laurie, S.S. Vascular remodeling in pulmonary hypertension. J. Mol. Med. (Berl.) 2013, 91, 297-309. [CrossRef] [PubMed]

4. Fulton, D.J.R.; Li, X.; Bordan, Z.; Haigh, S.; Bentley, A.; Chen, F.; Barman, S.A. Reactive Oxygen and Nitrogen Species in the Development of Pulmonary Hypertension. Antioxidants 2017, 6, 54. [CrossRef] [PubMed]

5. Domej, W.; Oettl, K.; Renner, W. Oxidative stress and free radicals in COPD-implications and relevance for treatment. Int. J. Chronic Obstruct. Pulm. Dis. 2014, 9, 1207-1224. [CrossRef] [PubMed]

6. Hoffman, S.; Nolin, J.; McMillan, D.; Wouters, E.; Janssen-Heininger, Y.; Reynaert, N. Thiol redox chemistry: Role of protein cysteine oxidation and altered redox homeostasis in allergic inflammation and asthma. J. Cell. Biochem. 2015, 116, 884-892. [CrossRef] [PubMed]

7. Geiszt, M.; Leto, T.L. The Nox family of NAD(P)H oxidases: Host defense and beyond. J. Biol. Chem. 2004, 279, 51715-51718. [CrossRef] [PubMed]

8. Lambeth, J.D. NOX enzymes and the biology of reactive oxygen. Nat. Rev. Immunol. 2004, 4, 181-189. [CrossRef] [PubMed]

9. Terada, L.S. Specificity in reactive oxidant signaling: Think globally, act locally. J. Cell Biol. 2006, 174, 615-623. [CrossRef] [PubMed]

10. Jones, R.D.; Hancock, J.T.; Morice, A.H. NADPH oxidase: A universal oxygen sensor? Free Radic. Biol. Med. 2000, 29, 416-424. [CrossRef]

11. Royce, S.G.; Li, X.; Tortorella, S.; Goodings, L.; Chow, B.S.; Giraud, A.S.; Tang, M.L.; Samuel, C.S. Mechanistic insights into the contribution of epithelial damage to airway remodeling. Novel therapeutic targets for asthma. Am. J. Respir. Cell Mol. Biol. 2014, 50, 180-192. [CrossRef] [PubMed]

12. Holgate, S.T.; Holloway, J.; Wilson, S.; Bucchieri, F.; Puddicombe, S.; Davies, D.E. Epithelial-mesenchymal communication in the pathogenesis of chronic asthma. Proc. Am. Thorac. Soc. 2004, 1, 93-98. [CrossRef] [PubMed]

13. Davies, D.E.; Polosa, R.; Puddicombe, S.M.; Richter, A.; Holgate, S.T. The epidermal growth factor receptor and its ligand family: Their potential role in repair and remodelling in asthma. Allergy 1999, 54, 771-783. [PubMed] 
14. Demoly, P.; Simony-Lafontaine, J.; Chanez, P.; Pujol, J.L.; Lequeux, N.; Michel, F.B.; Bousquet, J. Cell proliferation in the bronchial mucosa of asthmatics and chronic bronchitics. Am. J. Respir. Crit. Care Med. 1994, 150, 214-217. [CrossRef] [PubMed]

15. Barsky, S.H.; Roth, M.D.; Kleerup, E.C.; Simmons, M.; Tashkin, D.P. Histopathologic and molecular alterations in bronchial epithelium in habitual smokers of marijuana, cocaine and/or tobacco. J. Natl. Cancer Inst. 1998, 90, 1198-1205. [CrossRef] [PubMed]

16. Vignola, A.M.; Chanez, P.; Chiappara, G.; Merendino, A.; Pace, E.; Rizzo, A.; la Rocca, A.M.; Bellia, V.; Bonsignore, G.; Bousquet, J. Transforming growth factor-beta expression in mucosal biopsies in asthma and chronic bronchitis. Am. J. Respir. Crit. Care Med. 1997, 156, 591-599. [CrossRef] [PubMed]

17. Wu, D.; Lee, D.; Sung, Y.K. Prospect of vasoactive intestinal peptide therapy for COPD/PAH and asthma: A review. Respir. Res. 2011, 12, 45. [CrossRef] [PubMed]

18. Suresh, K.; Shimoda, L.A. Lung Circulation. Compr. Physiol. 2016, 6, 897-943. [PubMed]

19. Song, S.; Yamamura, A.; Yamamura, H.; Ayon, R.J.; Smith, K.A.; Tang, H.; Makino, A.; Yuan, J.X. Flow shear stress enhances intracellular $\mathrm{Ca}^{2+}$ signaling in pulmonary artery smooth muscle cells from patients with pulmonary arterial hypertension. Am. J. Physiol. Cell Physiol. 2014, 307, C373-C383. [CrossRef] [PubMed]

20. Papamatheakis, D.G.; Blood, A.B.; Kim, J.H.; Wilson, S.M. Antenatal hypoxia and pulmonary vascular function and remodeling. Curr. Vasc. Pharmacol. 2013, 11, 616-640. [CrossRef] [PubMed]

21. Eickelberg, O.; Morty, R.E. Transforming growth factor beta/bone morphogenic protein signaling in pulmonary arterial hypertension: Remodeling revisited. Trends Cardiovasc. Med. 2007, 17, 263-269. [CrossRef] [PubMed]

22. Hassoun, P.M.; Mouthon, L.; Barbera, J.A.; Eddahibi, S.; Flores, S.C.; Grimminger, F.; Jones, P.L.; Maitland, M.L.; Michelakis, E.D.; Morrell, N.W.; et al. Inflammation, growth factors and pulmonary vascular remodeling. J. Am. Coll. Cardiol. 2009, 54 (Suppl. S1), S10-S19. [CrossRef] [PubMed]

23. Groth, A.; Vrugt, B.; Brock, M.; Speich, R.; Ulrich, S.; Huber, L.C. Inflammatory cytokines in pulmonary hypertension. Respir. Res. 2014, 15, 47. [CrossRef] [PubMed]

24. Arcot, S.S.; Fagerland, J.A.; Lipke, D.W.; Gillespie, M.N.; Olson, J.W. Basic fibroblast growth factor alterations during development of monocrotaline-induced pulmonary hypertension in rats. Growth Factors 1995, 12, 121-130. [CrossRef] [PubMed]

25. Berg, J.T.; Breen, E.C.; Fu, Z.; Mathieu-Costello, O.; West, J.B. Alveolar hypoxia increases gene expression of extracellular matrix proteins and platelet-derived growth factor-B in lung parenchyma. Am. J. Respir. Crit. Care Med. 1998, 158, 1920-1928. [CrossRef] [PubMed]

26. Katayose, D.; Ohe, M.; Yamauchi, K.; Ogata, M.; Shirato, K.; Fujita, H.; Shibahara, S.; Takishima, T. Increased expression of PDGF A- and B-chain genes in rat lungs with hypoxic pulmonary hypertension. Am. J. Physiol. 1993, 264 Pt 1, L100-L106. [PubMed]

27. Perkett, E.A.; Badesch, D.B.; Roessler, M.K.; Stenmark, K.R.; Meyrick, B. Insulin-like growth factor I and pulmonary hypertension induced by continuous air embolization in sheep. Am. J. Respir. Cell Mol. Biol. 1992, 6, 82-87. [CrossRef] [PubMed]

28. Rahman, I.; MacNee, W. Regulation of redox glutathione levels and gene transcription in lung inflammation: Therapeutic approaches. Free Radic. Biol. Med. 2000, 28, 1405-1420. [CrossRef]

29. Rahman, I.; Mulier, B.; Gilmour, P.S.; Watchorn, T.; Donaldson, K.; Jeffery, P.K.; MacNee, W. Oxidant-mediated lung epithelial cell tolerance: The role of intracellular glutathione and nuclear factor-kB. Biochem. Pharmacol. 2001, 62, 787-794. [CrossRef]

30. Lee, J.H.; Kagan, E. Role of nicotinamide adenine dinucleotide phosphate oxidase in mediating vesicant-induced interleukin-6 secretion in human airway epithelial cell. Am. J. Respir. Cell Mol. Biol. 2014, 50, 713-722. [CrossRef] [PubMed]

31. Clark, R.A.; Valente, A.J. Nuclear factor B activation by NADPH oxidase. Mech. Ageing Dev. 2004, 125, 199-810. [CrossRef] [PubMed]

32. Gabelloni, M.L.; Sabbione, F.; Jancic, C.; Fuxman Bass, J.; Keitelman, I.; Iula, L.; Oleastro, M.; Geffner, J.R.; Trevani, A.S. NADPH oxidase derive reactive oxygen species are involved in human neutrophil IL-1 $\beta$ secretion but not in inflammasome activation. Eur. J. Immunol. 2013, 43, 3324-3325. [CrossRef] [PubMed]

33. Levenerence, J.T.; Medhora, M.; Konduri, G.G.; Sampath, V. Lipopolysaccharide-induced cytokine expression

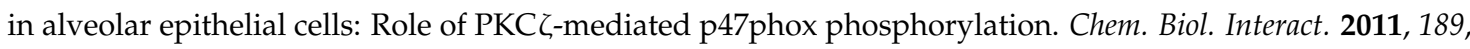
72-81. [CrossRef] [PubMed] 
34. Rabinovitch, M. Molecular pathogenesis of pulmonary arterial hypertension. J. Clin. Investig. 2008, 118, 2372-2379. [CrossRef] [PubMed]

35. Liu, J.Q.; Zelko, I.N.; Erbynn, E.M.; Sham, J.S.; Folz, R.J. Hypoxic pulmonary hypertension: Role of superoxide and NADPH oxidase (gp91phox). Am. J. Physiol. Lung Cell. Mol. Physiol. 2006, 290, L2-L10. [CrossRef] [PubMed]

36. Carnesecchi, S.; Deffert, C.; Pagano, A.; Garrido-Urbani, S.; Metrailler-Ruchonnet, I.; Schappi, M.; Donati, Y.; Matthay, M.A.; Krause, K.H.; Barazzone Argiroffo, C. NADPH oxidase-1 plays a crucial role in hyperoxia-induced acute lung injury in mice. Am. J. Respir. Crit. Care Med. 2009, 180, 972-981. [CrossRef] [PubMed]

37. Berkelhamer, S.K.; Kim, G.A.; Radder, J.E.; Wedgwood, S.; Czech, L.; Steinhorn, R.H.; Schumacker, P.T. Developmental differences in hyperoxia-induced oxidative stress and cellular responses in the murine lung. Free Radic. Biol. Med. 2013, 61, 51-60. [CrossRef] [PubMed]

38. Dennis, K.E.; Aschner, J.L.; Milatovic, D.; Schmidt, J.W.; Aschner, M.; Kaplowitz, M.R.; Zhang, Y.; Fike, C.D. NADPH oxidases and reactive oxygen species at different stages of chronic hypoxia-induced pulmonary hypertension in newborn piglets. Am. J. Physiol. Lung Cell. Mol. Physiol. 2009, 297, L596-L607. [CrossRef] [PubMed]

39. Veit, F.; Pak, O.; Egemnazarov, B.; Roth, M.; Kosanovic, D.; Seimetz, M.; Sommer, N.; Ghofrani, H.A.; Seeger, W.; Grimminger, F.; et al. Function of NADPH oxidase 1 in pulmonary arterial smooth muscle cells after monocrotaline-induced pulmonary vascular remodeling. Antioxid. Redox Signal. 2013, 19, 2213-2231. [CrossRef] [PubMed]

40. Kameshima, S.; Kazama, K.; Okada, M.; Yamawaki, H. Eukaryotic elongation factor 2 kinase mediates monocrotaline-induced pulmonary arterial hypertension via reactive oxygen species-dependent vascular remodeling. Am. J. Physiol. Heart Circ. Physiol. 2015, 308, H1298-H1305. [CrossRef] [PubMed]

41. Hood, K.Y.; Montezano, A.C.; Harvey, A.P.; Nilsen, M.; MacLean, M.R.; Touyz, R.M. Nicotinamide Adenine Dinucleotide Phosphate Oxidase-Mediated Redox Signaling and Vascular Remodeling by 16alpha-Hydroxyestrone in Human Pulmonary Artery Cells: Implications in Pulmonary Arterial Hypertension. Hypertension 2016, 68, 796-808. [CrossRef] [PubMed]

42. Ghouleh, I.A.; Sahoo, S.; Meijles, D.N.; Amaral, J.H.; de Jesus, D.S.; Sembrat, J.; Rojas, M.; Goncharov, D.A.; Goncharova, E.A.; Pagano, P.J. Endothelial Nox1 Oxidase Assembly in Human Pulmonary Arterial Hypertension; Driver of Gremlin1-Medziated Proliferation. Clin. Sci. (Lond.) 2017, 131, 2019-2035. [CrossRef] [PubMed]

43. Iwata, K.; Ikami, K.; Matsuno, K.; Yamashita, T.; Shiba, D.; Ibi, M.; Matsumoto, M.; Katsuyama, M.; Cui, W.; Zhang, J.; et al. Deficiency of NOX1/nicotinamide adenine dinucleotide phosphate, reduced form oxidase leads to pulmonary vascular remodeling. Arterioscler. Thromb. Vasc. Biol. 2014, 34, 110-119. [CrossRef] [PubMed]

44. Brennan, L.A.; Steinhorn, R.H.; Wedgwood, S.; Mata-Greenwood, E.; Roark, E.A.; Russell, J.A.; Black, S.M. Increased superoxide generation is associated with pulmonary hypertension in fetal lambs: A role for NADPH oxidase. Circ. Res. 2003, 92, 683-691. [CrossRef] [PubMed]

45. Fike, C.D.; Slaughter, J.C.; Kaplowitz, M.R.; Zhang, Y.; Aschner, J.L. Reactive oxygen species from NADPH oxidase contribute to altered pulmonary vascular responses in piglets with chronic hypoxia-induced pulmonary hypertension. Am. J. Physiol. Lung Cell. Mol. Physiol. 2008, 295, L881-L888. [CrossRef] [PubMed]

46. Wedgwood, S.; Lakshminrusimha, S.; Farrow, K.N.; Czech, L.; Gugino, S.F.; Soares, F.; Russell, J.A.; Steinhorn, R.H. Apocynin improves oxygenation and increases eNOS in persistent pulmonary hypertension of the newborn. Am. J. Physiol. Lung Cell. Mol. Physiol. 2012, 302, L616-L626. [CrossRef] [PubMed]

47. Mittal, M.; Roth, M.; Konig, P.; Hofmann, S.; Dony, E.; Goyal, P.; Selbitz, A.C.; Schermuly, R.T.; Ghofrani, H.A.; Kwapiszewska, G.; et al. Hypoxia-dependent regulation of nonphagocytic NADPH oxidase subunit NOX4 in the pulmonary vasculature. Circ. Res. 2007, 101, 258-267. [CrossRef] [PubMed]

48. Liu, B.; Li, T.; Peng, J.J.; Zhang, J.J.; Liu, W.Q.; Luo, X.J.; Ma, Q.L.; Gong, Z.C.; Peng, J. Non-muscle myosin light chain promotes endothelial progenitor cells senescence and dysfunction in pulmonary hypertensive rats through up-regulation of NADPH oxidase. Eur. J. Pharmacol. 2016, 775, 67-77. [CrossRef] [PubMed] 
49. Liu, B.; Luo, X.J.; Yang, Z.B.; Zhang, J.J.; Li, T.B.; Zhang, X.J.; Ma, Q.L.; Zhang, G.G.; Hu, C.P.; Peng, J. Inhibition of NOX/VPO1 pathway and inflammatory reaction by trimethoxystilbene in prevention of cardiovascular remodeling in hypoxia-induced pulmonary hypertensive rats. J. Cardiovasc. Pharmacol. 2014, 63, 567-576. [CrossRef] [PubMed]

50. Djordjevic, T.; BelAiba, R.S.; Bonello, S.; Pfeilschifter, J.; Hess, J.; Gorlach, A. Human urotensin II is a novel activator of NADPH oxidase in human pulmonary artery smooth muscle cells. Arterioscler. Thromb. Vasc. Biol. 2005, 25, 519-525. [CrossRef] [PubMed]

51. Sturrock, A.; Huecksteadt, T.P.; Norman, K.; Sanders, K.; Murphy, T.M.; Chitano, P.; Wilson, K.; Hoidal, J.R.; Kennedy, T.P. Nox4 mediates TGF-beta1-induced retinoblastoma protein phosphorylation, proliferation and hypertrophy in human airway smooth muscle cells. Am. J. Physiol. Lung Cell. Mol. Physiol. 2007, 292, L1543-L1555. [CrossRef] [PubMed]

52. Sturrock, A.; Cahill, B.; Norman, K.; Huecksteadt, T.P.; Hill, K.; Sanders, K.; Karwande, S.V.; Stringham, J.C.; Bull, D.A.; Gleich, M.; et al. Transforming growth factor-beta1 induces Nox4 NAD(P)H oxidase and reactive oxygen species-dependent proliferation in human pulmonary artery smooth muscle cells. Am. J. Physiol. Lung Cell. Mol. Physiol. 2006, 290, L661-L673. [CrossRef] [PubMed]

53. Ge, A.; Ma, Y.; Liu, Y.N.; Li, Y.S.; Gu, H.; Zhang, J.X.; Wang, Q.X.; Zeng, X.N.; Huang, M. Diosmetin prevents TGF-beta1-induced epithelial-mesenchymal transition via ROS/MAPK signaling pathways. Life Sci. 2016, 153, 1-8. [CrossRef] [PubMed]

54. Tong, X.; Hou, X.; Jourd'heuil, D.; Weisbrod, R.M.; Cohen, R.A. Upregulation of Nox4 by TGF $\beta 1$ oxidizes SERCA and inhibits NO in arterial smooth muscle of the prediabetic Zucker rat. Circ. Res. 2010, 107, 975-983. [CrossRef] [PubMed]

55. Hecker, L.; Vittal, R.; Jones, T.; Jagirdar, R.; Luckhardt, T.R.; Horowitz, J.C.; Pennathur, S.; Martinez, F.J.; Thannickal, V.J. NADPH oxidase-4 mediates myofibroblast activation and fibrogenic responses to lung injury. Nat. Med. 2009, 15, 1077-1081. [CrossRef] [PubMed]

56. Berk, B.C. Vascular smooth muscle growth: Autocrine growth mechanisms. Physiol. Rev. 2001, 81, 999-1030. [PubMed]

57. Morrell, N.W.; Yang, X.; Upton, P.D.; Jourdan, K.B.; Morgan, N.; Sheares, K.K.; Trembath, R.C. Altered growth responses of pulmonary artery smooth muscle cells from patients with primary pulmonary hypertension to transforming growth factor-beta(1) and bone morphogenetic proteins. Circulation 2001, 104, 790-795. [CrossRef] [PubMed]

58. Perkett, E.A.; Lyons, R.M.; Moses, H.L.; Brigham, K.L.; Meyrick, B. Transforming growth factor-beta activity in sheep lung lymph during the development of pulmonary hypertension. J. Clin. Investig. 1990, 86, 1459-1464. [CrossRef] [PubMed]

59. Sheares, K.K.; Jeffery, T.K.; Long, L.; Yang, X.; Morrell, N.W. Differential effects of TGF-beta1 and BMP-4 on the hypoxic induction of cyclooxygenase-2 in human pulmonary artery smooth muscle cells. Am. J. Physiol. Lung Cell. Mol. Physiol. 2004, 287, L919-L927. [CrossRef] [PubMed]

60. Ma, L.; Ambalavanan, N.; Liu, H.; Sun, Y.; Jhala, N.; Bradley, W.E.; Dell'Italia, L.J.; Michalek, S.; Wu, H.; Steele, C.; et al. TLR4 regulates pulmonary vascular homeostasis and remodeling via redox signaling. Front. Biosci. (Landmark Ed.) 2016, 21, 397-409. [PubMed]

61. Lu, X.; Murphy, T.C.; Nanes, M.S.; Hart, C.M. PPAR $\lambda$ regulates hypoxia-induced Nox4 expression in human pulmonary artery smooth muscle cells through NF-кB. Am. J. Physiol. Lung Cell. Mol. Physiol. 2010, 299, L559-L566. [CrossRef] [PubMed]

62. Mittal, S.; Marshall, N.A.; Barker, R.N.; Vickers, M.A. Immunomodulation against leukemias and lymphomas: A realistic future treatment? Crit. Rev. Oncol. Hematol. 2008, 65, 101-108. [CrossRef] [PubMed]

63. Usatyuk, P.V.; Fu, P.; Mohan, V.; Epshtein, Y.; Jacobson, J.R.; Gomez-Cambronero, J.; Wary, K.K.; Bindokas, V.; Dudek, S.M.; Salgia, R.; et al. Role of c-Met/phosphatidylinositol 3-kinase (PI3k)/Akt signaling in hepatocyte growth factor (HGF)-mediated lamellipodia formation, reactive oxygen species (ROS) generation and motility of lung endothelial cells. J. Biol. Chem. 2014, 289, 13476-13491. [CrossRef] [PubMed]

64. Harijith, A.; Pendyala, S.; Ebenezer, D.L.; Ha, A.W.; Fu, P.; Wang, Y.T.; Ma, K.; Toth, P.T.; Berdyshev, E.V.; Kanteti, P.; et al. Hyperoxia-induced p47phox activation and ROS generation is mediated through S1P transporter Spns2 and S1P/S1P1\&2 signaling axis in lung endothelium. Am. J. Physiol. Lung Cell. Mol. Physiol. 2016, 311, L337-L351. [PubMed] 
65. Chen, J.; Tang, H.; Sysol, J.R.; Moreno-Vinasco, L.; Shioura, K.M.; Chen, T.; Gorshkova, I.; Wang, L.; Huang, L.S.; Usatyuk, P.V.; et al. The sphingosine kinase 1/sphingosine-1-phosphate pathway in pulmonary arterial hypertension. Am. J. Respir. Crit. Care Med. 2014, 190, 1032-1043. [CrossRef] [PubMed]

66. Horvath, I.; Hunt, J.; Barnes, P.J.; Alving, K.; Antczak, A.; Baraldi, E.; Becher, G.; van Beurden, W.J.; Corradi, M.; Dekhuijzen, R.; et al. Exhaled breath condensate: Methodological recommendations and unresolved questions. Eur. Respir. J. 2005, 26, 523-548. [CrossRef] [PubMed]

67. Dekhuijzen, P.N.; Aben, K.K.; Dekker, I.; Aarts, L.P.; Wielders, P.L.; van Herwaarden, C.L.; Bast, A. Increased exhalation of hydrogen peroxide in patients with stable and unstable chronic obstructive pulmonary disease. Am. J. Respir. Crit. Care Med. 1996, 154 Pt 1, 813-816. [CrossRef] [PubMed]

68. Nowak, D.; Kasielski, M.; Antczak, A.; Pietras, T.; Bialasiewicz, P. Increased content of thiobarbituric acid-reactive substances and hydrogen peroxide in the expired breath condensate of patients with stable chronic obstructive pulmonary disease: No significant effect of cigarette smoking. Respir. Med. 1999, 93, 389-396. [CrossRef] [PubMed]

69. Morrow, J.D.; Hill, K.E.; Burk, R.F.; Nammour, T.M.; Badr, K.F.; Roberts, L.J., 2nd. A series of prostaglandin F2-like compounds are produced in vivo in humans by a non-cyclooxygenase, free radical-catalyzed mechanism. Proc. Natl. Acad. Sci. USA 1990, 87, 9383-9387. [CrossRef] [PubMed]

70. Bartoli, M.L.; Novelli, F.; Costa, F.; Malagrino, L.; Melosini, L.; Bacci, E.; Cianchetti, S.; Dente, F.L.; Di Franco, A.; Vagaggini, B.; et al. Malondialdehyde in exhaled breath condensate as a marker of oxidative stress in different pulmonary diseases. Mediat. Inflamm. 2011, 2011, 891752. [CrossRef] [PubMed]

71. Liu, X.; Hao, B.; Ma, A.; He, J.; Liu, X.; Chen, J. The Expression of NOX4 in Smooth Muscles of Small Airway Correlates with the Disease Severity of COPD. BioMed Res. Int. 2016, 2016, 2891810. [CrossRef] [PubMed]

72. Van Eeden, S.F.; Sin, D.D. Oxidative stress in chronic obstructive pulmonary disease: A lung and systemic process. Can. Respir. J. 2013, 20, 27-29. [CrossRef] [PubMed]

73. Hollins, F.; Sutcliffe, A.; Gomez, E.; Berair, R.; Russell, R.; Szyndralewiez, C.; Saunders, R.; Brightling, C. Airway smooth muscle NOX4 is upregulated and modulates ROS generation in COPD. Respir. Res. 2016, 17, 84. [CrossRef] [PubMed]

74. Michaeloudes, C.; Sukkar, M.B.; Khorasani, N.M.; Bhavsar, P.K.; Chung, K.F. TGF-beta regulates Nox4, MnSOD and catalase expression and IL-6 release in airway smooth muscle cells. Am. J. Physiol. Lung Cell. Mol. Physiol. 2011, 300, L295-L304. [CrossRef] [PubMed]

75. Sutcliffe, A.; Hollins, F.; Gomez, E.; Saunders, R.; Doe, C.; Cooke, M.; Challiss, R.A.; Brightling, C.E. Increased nicotinamide adenine dinucleotide phosphate oxidase 4 expression mediates intrinsic airway smooth muscle hypercontractility in asthma. Am. J. Respir. Crit. Care Med. 2012, 185, 267-274. [CrossRef] [PubMed]

76. Brar, S.S.; Kennedy, T.P.; Sturrock, A.B.; Huecksteadt, T.P.; Quinn, M.T.; Murphy, T.M.; Chitano, P.; Hoidal, J.R. NADPH oxidase promotes NF- $\mathrm{B}$ activation and proliferation in human airway smooth muscle. Am. J. Physiol. Lung Cell. Mol. Physiol. 2002, 282, L782-L795. [CrossRef] [PubMed]

77. Page, K.; Li, J.; Hodge, J.A.; Liu, P.T.; Vanden Hoek, T.L.; Becker, L.B.; Pestell, R.G.; Rosner, M.R.; Hershenson, M.B. Characterization of a Rac1 signaling pathway to cyclin $\mathrm{D}(1)$ expression in airway smooth muscle cells. J. Biol. Chem. 1999, 274, 22065-22071. [CrossRef] [PubMed]

78. Talbot, S.; Lin, J.C.; Lahjouji, K.; Roy, J.P.; Senecal, J.; Morin, A.; Couture, R. Cigarette smoke-induced kinin B1 receptor promotes NADPH oxidase activity in cultured human alveolar epithelial cells. Peptides 2011, 32, 1447-1456. [CrossRef] [PubMed]

79. Schneider, D.; Ganesan, S.; Comstock, A.T.; Meldrum, C.A.; Mahidhara, R.; Goldsmith, A.M.; Curtis, J.L.; Martinez, F.J.; Hershenson, M.B.; Sajjan, U. Increased cytokine response of rhinovirus-infected airway epithelial cells in chronic obstructive pulmonary disease. Am. J. Respir. Crit. Care Med. 2010, 182, 332-340. [CrossRef] [PubMed]

80. Nagai, K.; Betsuyaku, T.; Suzuki, M.; Nasuhara, Y.; Kaga, K.; Kondo, S.; Nishimura, M. Dual oxidase 1 and 2 expression in airway epithelium of smokers and patients with mild/moderate chronic obstructive pulmonary disease. Antioxid. Redox Signal. 2008, 10, 705-714. [CrossRef] [PubMed]

81. Bidan, C.M.; Veldsink, A.C.; Meurs, H.; Gosens, R. Airway and Extracellular Matrix Mechanics in COPD. Front. Physiol. 2015, 6, 346. [CrossRef] [PubMed]

82. Black, P.N.; Ching, P.S.; Beaumont, B.; Ranasinghe, S.; Taylor, G.; Merrilees, M.J. Changes in elastic fibres in the small airways and alveoli in COPD. Eur. Respir. J. 2008, 31, 998-1004. [CrossRef] [PubMed] 
83. Hallgren, O.; Nihlberg, K.; Dahlback, M.; Bjermer, L.; Eriksson, L.T.; Erjefalt, J.S.; Lofdahl, C.G.; Westergren-Thorsson, G. Altered fibroblast proteoglycan production in COPD. Respir. Res. 2010, 11, 55. [CrossRef] [PubMed]

84. Cucoranu, I.; Clempus, R.; Dikalova, A.; Phelan, P.J.; Ariyan, S.; Dikalov, S.; Sorescu, D. NAD(P)H oxidase 4 mediates transforming growth factor-beta1-induced differentiation of cardiac fibroblasts into myofibroblasts. Circ. Res. 2005, 97, 900-907. [CrossRef] [PubMed]

85. Rees, M.D.; Kennett, E.C.; Whitelock, J.M.; Davies, M.J. Oxidative damage to extracellular matrix and its role in human pathologies. Free Radic. Biol. Med. 2008, 44, 1973-2001. [CrossRef] [PubMed]

86. Barth, D.; Kyrieleis, O.; Frank, S.; Renner, C.; Moroder, L. The role of cystine knots in collagen folding and stability, part II. Conformational properties of (Pro-Hyp-Gly)n model trimers with N- and C-terminal collagen type III cystine knots. Chemistry 2003, 9, 3703-3714. [CrossRef] [PubMed]

87. Wilkes, D.S.; Chew, T.; Flaherty, K.R.; Frye, S.; Gibson, K.F.; Kaminski, N.; Klemsz, M.J.; Lange, W.; Noth, I.; Rothhaar, K. Oral immunotherapy with type V collagen in idiopathic pulmonary fibrosis. Eur. Respir. J. 2015, 45, 1393-1402. [CrossRef] [PubMed]

88. Taraseviciene-Stewart, L.; Voelkel, N.F. Molecular pathogenesis of emphysema. J. Clin. Investig. 2008, 118, 394-402. [CrossRef] [PubMed]

89. Trocme, C.; Deffert, C.; Cachat, J.; Donati, Y.; Tissot, C.; Papacatzis, S.; Braunersreuther, V.; Pache, J.C.; Krause, K.H.; Holmdahl, R.; et al. Macrophage-specific NOX2 contributes to the development of lung emphysema through modulation of SIRT1/MMP-9 pathways. J. Pathol. 2015, 235, 65-78. [CrossRef] [PubMed]

90. Noguera, A.; Busquets, X.; Sauleda, J.; Villaverde, J.M.; MacNee, W.; Agusti, A.G. Expression of adhesion molecules and $\mathrm{G}$ proteins in circulating neutrophils in chronic obstructive pulmonary disease. Am. J. Respir. Crit. Care Med. 1998, 158 Pt 1, 1664-1668. [CrossRef] [PubMed]

91. Noguera, A.; Batle, S.; Miralles, C.; Iglesias, J.; Busquets, X.; MacNee, W.; Agusti, A.G. Enhanced neutrophil response in chronic obstructive pulmonary disease. Thorax 2001, 56, 432-437. [CrossRef] [PubMed]

92. Keatings, V.M.; Collins, P.D.; Scott, D.M.; Barnes, P.J. Differences in interleukin-8 and tumor necrosis factor-alpha in induced sputum from patients with chronic obstructive pulmonary disease or asthma. Am. J. Respir. Crit. Care Med. 1996, 153, 530-534. [CrossRef] [PubMed]

93. Zhou, M.J.; Brown, E.J. CR3 (Mac-1, alpha M beta 2, CD11b/CD18) and Fc gamma RIII cooperate in generation of a neutrophil respiratory burst: Requirement for FC gamma RIII and tyrosine phosphorylation. J. Cell Biol. 1994, 125, 1407-1416. [CrossRef] [PubMed]

94. Lowell, C.A.; Fumagalli, L.; Berton, G. Deficiency of Src family kinases p59/61hck and p58c-fgr results in defective adhesion-dependent neutrophil functions. J. Cell Biol. 1996, 133, 895-910. [CrossRef] [PubMed]

95. Liles, W.C.; Ledbetter, J.A.; Waltersdorph, A.W.; Klebanoff, S.J. Cross-linking of CD18 primes human neutrophils for activation of the respiratory burst in response to specific stimuli: Implications for adhesion-dependent physiological responses in neutrophils. J. Leukoc. Biol. 1995, 58, 690-697. [PubMed]

96. Zhang, X.; Shan, P.; Qureshi, S.; Homer, R.; Medzhitov, R.; Noble, P.W.; Lee, P.J. Cutting edge: TLR4 deficiency confers susceptibility to lethal oxidant lung injury. J. Immunol. 2005, 175, 4834-4838. [CrossRef] [PubMed]

97. Jiang, D.; Liang, J.; Fan, J.; Yu, S.; Chen, S.; Luo, Y.; Prestwich, G.D.; Mascarenhas, M.M.; Garg, H.G.; Quinn, D.A.; et al. Regulation of lung injury and repair by Toll-like receptors and hyaluronan. Nat. Med. 2005, 11, 1173-1179. [CrossRef] [PubMed]

98. Qureshi, S.T.; Zhang, X.; Aberg, E.; Bousette, N.; Giaid, A.; Shan, P.; Medzhitov, R.M.; Lee, P.J. Inducible activation of TLR4 confers resistance to hyperoxia-induced pulmonary apoptosis. J. Immunol. 2006, 176, 4950-4958. [CrossRef] [PubMed]

99. Zhang, X.; Shan, P.; Jiang, G.; Cohn, L.; Lee, P.J. Toll-like receptor 4 deficiency causes pulmonary emphysema. J. Clin. Investig. 2006, 116, 3050-3059. [CrossRef] [PubMed]

100. Yao, H.; Edirisinghe, I.; Yang, S.R.; Rajendrasozhan, S.; Kode, A.; Caito, S.; Adenuga, D.; Rahman, I. Genetic ablation of NADPH oxidase enhances susceptibility to cigarette smoke-induced lung inflammation and emphysema in mice. Am. J. Pathol. 2008, 172, 1222-1237. [CrossRef] [PubMed]

101. Wagner, E.M. The role of the tracheobronchial circulation in aerosol clearance. J. Aerosol Med. 1995, 8, 1-5. [CrossRef] [PubMed]

102. Csete, M.E.; Chediak, A.D.; Abraham, W.M.; Wanner, A. Airway blood flow modifies allergic airway smooth muscle contraction. Am. Rev. Respir. Dis. 1991, 144, 59-63. [CrossRef] [PubMed] 
103. Flood-Page, P.; Menzies-Gow, A.; Phipps, S.; Ying, S.; Wangoo, A.; Ludwig, M.S.; Barnes, N.; Robinson, D.; Kay, A.B. Anti-IL-5 treatment reduces deposition of ECM proteins in the bronchial subepithelial basement membrane of mild atopic asthmatics. J. Clin. Investig. 2003, 112, 1029-1036. [CrossRef] [PubMed]

104. Le Cras, T.D.; Acciani, T.H.; Mushaben, E.M.; Kramer, E.L.; Pastura, P.A.; Hardie, W.D.; Korfhagen, T.R.; Sivaprasad, U.; Ericksen, M.; Gibson, A.M.; et al. Epithelial EGF receptor signaling mediates airway hyperreactivity and remodeling in a mouse model of chronic asthma. Am. J. Physiol. Lung Cell. Mol. Physiol. 2011, 300, L414-L421. [CrossRef] [PubMed]

105. Sidhu, S.S.; Yuan, S.; Innes, A.L.; Kerr, S.; Woodruff, P.G.; Hou, L.; Muller, S.J.; Fahy, J.V. Roles of epithelial cell-derived periostin in TGF-beta activation, collagen production and collagen gel elasticity in asthma. Proc. Natl. Acad. Sci. USA 2010, 107, 14170-14175. [CrossRef] [PubMed]

106. Andreadis, A.A.; Hazen, S.L.; Comhair, S.A.; Erzurum, S.C. Oxidative and nitrosative events in asthma. Free Radic. Biol. Med. 2003, 35, 213-225. [CrossRef]

107. Wedes, S.H.; Khatri, S.B.; Zhang, R.; Wu, W.; Comhair, S.A.; Wenzel, S.; Teague, W.G.; Israel, E.; Erzurum, S.C.; Hazen, S.L. Noninvasive markers of airway inflammation in asthma. Clin. Transl. Sci. 2009, 2, 112-117. [CrossRef] [PubMed]

108. Owayed, A.; Dhaunsi, G.S.; Al-Mukhaizeem, F. Nitric oxide-mediated activation of NADPH oxidase by salbutamol during acute asthma in children. Cell Biochem. Funct. 2008, 26, 603-608. [CrossRef] [PubMed]

109. Geiszt, M.; Witta, J.; Baffi, J.; Lekstrom, K.; Leto, T.L. Dual oxidases represent novel hydrogen peroxide sources supporting mucosal surface host defense. FASEB J. 2003, 17, 1502-1504. [CrossRef] [PubMed]

110. Schwarzer, C.; Machen, T.E.; Illek, B.; Fischer, H. NADPH oxidase-dependent acid production in airway epithelial cells. J. Biol. Chem. 2004, 279, 36454-36461. [CrossRef] [PubMed]

111. Fischer, H.; Gonzales, L.K.; Kolla, V.; Schwarzer, C.; Miot, F.; Illek, B.; Ballard, P.L. Developmental regulation of DUOX1 expression and function in human fetal lung epithelial cells. Am. J. Physiol. Lung Cell. Mol. Physiol. 2007, 292, L1506-L1514. [CrossRef] [PubMed]

112. Tyner, J.W.; Kim, E.Y.; Ide, K.; Pelletier, M.R.; Roswit, W.T.; Morton, J.D.; Battaile, J.T.; Patel, A.C.; Patterson, G.A.; Castro, M.; et al. Blocking airway mucous cell metaplasia by inhibiting EGFR antiapoptosis and IL-13 transdifferentiation signals. J. Clin. Investig. 2006, 116, 309-321. [CrossRef] [PubMed]

113. Habibovic, A.; Hristova, M.; Heppner, D.E.; Danyal, K.; Ather, J.L.; Janssen-Heininger, Y.M.; Irvin, C.G.; Poynter, M.E.; Lundblad, L.K.; Dixon, A.E.; et al. DUOX1 mediates persistent epithelial EGFR activation, mucous cell metaplasia and airway remodeling during allergic asthma. JCI Insight 2016, 1, e88811. [CrossRef] [PubMed]

114. Shao, M.X.; Nadel, J.A. Dual oxidase 1-dependent MUC5AC mucin expression in cultured human airway epithelial cells. Proc. Natl. Acad. Sci. USA 2005, 102, 767-772. [CrossRef] [PubMed]

115. Atkinson, J.J.; Senior, R.M. Matrix metalloproteinase-9 in lung remodeling. Am. J. Respir. Cell Mol. Biol. 2003, 28, 12-24. [CrossRef] [PubMed]

116. Ricciardolo, F.L.; Gaston, B.; Hunt, J. Acid stress in the pathology of asthma. J. Allergy Clin. Immunol. 2004, 113, 610-619. [CrossRef] [PubMed]

117. Wan, W.Y.; Hollins, F.; Haste, L.; Woodman, L.; Hirst, R.A.; Bolton, S.; Gomez, E.; Sutcliffe, A.; Desai, D.; Chachi, L.; et al. NADPH Oxidase-4 Overexpression Is Associated With Epithelial Ciliary Dysfunction in Neutrophilic Asthma. Chest 2016, 149, 1445-1459. [CrossRef] [PubMed]

118. Amara, N.; Bachoual, R.; Desmard, M.; Golda, S.; Guichard, C.; Lanone, S.; Aubier, M.; Ogier-Denis, E.; Boczkowski, J. Diesel exhaust particles induce matrix metalloprotease-1 in human lung epithelial cells via a NADP(H) oxidase/NOX4 redox-dependent mechanism. Am. J. Physiol. Lung Cell. Mol. Physiol. 2007, 293, L170-L181. [CrossRef] [PubMed]

119. Kim, H.J.; Park, Y.D.; Moon, U.Y.; Kim, J.H.; Jeon, J.H.; Lee, J.G.; Bae, Y.S.; Yoon, J.H. The role of Nox4 in oxidative stress-induced MUC5AC overexpression in human airway epithelial cells. Am. J. Respir. Cell Mol. Biol. 2008, 39, 598-609. [CrossRef] [PubMed]

120. Jacobsen, E.A.; Taranova, A.G.; Lee, N.A.; Lee, J.J. Eosinophils: Singularly destructive effector cells or purveyors of immunoregulation? J. Allergy Clin. Immunol. 2007, 119, 1313-1320. [CrossRef] [PubMed]

121. Fahy, J.V. Eosinophilic and neutrophilic inflammation in asthma: Insights from clinical studies. Proc. Am. Thorac. Soc. 2009, 6, 256-259. [CrossRef] [PubMed]

122. Banerjee, E.R.; Henderson, W.R., Jr. Role of T cells in a gp91phox knockout murine model of acute allergic asthma. Allergy Asthma Clin. Immunol. 2013, 9, 6. [CrossRef] [PubMed] 
123. Banerjee, E.R.; Henderson, W.R., Jr. Defining the molecular role of gp91phox in the immune manifestation of acute allergic asthma using a preclinical murine model. Clin. Mol. Allergy 2012, 10, 2. [CrossRef] [PubMed]

124. Abdala-Valencia, H.; Earwood, J.; Bansal, S.; Jansen, M.; Babcock, G.; Garvy, B.; Wills-Karp, M.; Cook-Mills, J.M. Nonhematopoietic NADPH oxidase regulation of lung eosinophilia and airway hyperresponsiveness in experimentally induced asthma. Am. J. Physiol. Lung Cell. Mol. Physiol. 2007, 292, L1111-L1125. [CrossRef] [PubMed]

125. Boldogh, I.; Bacsi, A.; Choudhury, B.K.; Dharajiya, N.; Alam, R.; Hazra, T.K.; Mitra, S.; Goldblum, R.M.; Sur, S. ROS generated by pollen NADPH oxidase provide a signal that augments antigen-induced allergic airway inflammation. J. Clin. Investig. 2005, 115, 2169-2179. [CrossRef] [PubMed]

126. Datta, A.; Kim, G.A.; Taylor, J.M.; Gugino, S.F.; Farrow, K.N.; Schumacker, P.T.; Berkelhamer, S.K. Mouse lung development and NOX1 induction during hyperoxia are developmentally regulated and mitochondrial ROS dependent. Am. J. Physiol. Lung Cell. Mol. Physiol. 2015, 309, L369-L377. [CrossRef] [PubMed]

127. Rajashekhar, G.; Kamocka, M.; Marin, A.; Suckow, M.A.; Wolter, W.R.; Badve, S.; Sanjeevaiah, A.R.; Pumiglia, K.; Rosen, E.; Clauss, M. Pro-inflammatory angiogenesis is mediated by p38 MAP kinase. J. Cell. Physiol. 2011, 226, 800-808. [CrossRef] [PubMed]

128. Menden, H.; Tate, E.; Hogg, N.; Sampath, V. LPS-mediated endothelial activation in pulmonary endothelial cells: Role of Nox2-dependent IKK-beta phosphorylation. Am. J. Physiol. Lung Cell. Mol. Physiol. 2013, 304, L445-L455. [CrossRef] [PubMed]

129. Menden, H.; Welak, S.; Cossette, S.; Ramchandran, R.; Sampath, V. Lipopolysaccharide (LPS)-mediated angiopoietin-2-dependent autocrine angiogenesis is regulated by NADPH oxidase 2 (Nox2) in human pulmonary microvascular endothelial cells. J. Biol. Chem. 2015, 290, 5449-5461. [CrossRef] [PubMed]

130. Harijith, A.; Pendyala, S.; Reddy, N.M.; Bai, T.; Usatyuk, P.V.; Berdyshev, E.; Gorshkova, I.; Huang, L.S.; Mohan, V.; Garzon, S.; et al. Sphingosine kinase 1 deficiency confers protection against hyperoxia-induced bronchopulmonary dysplasia in a murine model: Role of S1P signaling and Nox proteins. Am. J. Pathol. 2013, 183, 1169-1182. [CrossRef] [PubMed]

131. Sharma, A.K.; LaPar, D.J.; Stone, M.L.; Zhao, Y.; Mehta, C.K.; Kron, I.L.; Laubach, V.E. NOX2 activation of natural killer T cells is blocked by the adenosine A2A receptor to inhibit lung ischemia-reperfusion injury. Am. J. Respir. Crit. Care Med. 2016, 193, 988-999. [CrossRef] [PubMed]

132. Altenhöfer, S.; Radermacher, K.A.; Kleikers, P.W.; Wingler, K.; Schmidt, H.H. Evolution of NADPH oxidase inhibitors: Selectivity and mechanisms for target engagement. Antioxid. Redox Signal. 2015, 23, 406-427. [CrossRef] [PubMed]

133. Green, D.E.; Murphy, T.C.; Kang, B.Y.; Kleinhenz, J.M.; Szyndralewiez, C.; Page, P.; Sutliff, R.L.; Hart, C.M. The Nox4 inhibitor GKT137831 attenuates hypoxia-induced pulmonary vascular cell proliferation. Am. J. Respir. Cell Mol. Biol. 2012, 47, 718-726. [CrossRef] [PubMed]

134. Wang, Y.X.; Zheng, Y.M. ROS-dependent signaling mechanisms for hypoxic $\mathrm{Ca}^{2+}$ responses in pulmonary artery myocytes. Antioxid. Redox Signal. 2010, 12, 611-623. [CrossRef] [PubMed]

135. Kim, S.Y.; Moon, K.A.; Jo, H.Y.; Jeong, S.; Seon, S.H.; Jung, E.; Cho, Y.S.; Chun, E.; Lee, K.Y. Anti-inflammatory effects of apocynin, an inhibitor of NADPH oxidase, in airway inflammation. Immunol. Cell Biol. 2012, 90, 441-448. [CrossRef] [PubMed]

136. Moldeus, P.; Berggren, M.; Graffström, R. N-acetylcysteine protection against the toxicity of cigarette smoke and cigarette smoke condensates in various tissues and cells in vitro. Eur. J. Respir. Dis. 1985, 66 (Suppl. S139), 123-129.

137. Stey, C.; Steurer, J.; Bachmann, S. The effect of oral $N$-acetylcysteine in chronic bronchitis: A quantitative systematic review. Eur. Respir. J. 2000, 16, 253-262. [CrossRef] [PubMed]

138. Linden, M.; Wieslander, E.; Eklund, A. Effects of oral $N$-acetylcysteine on cell content and macrophage function in bronchoalveolar lavage from healthy smokers. Eur. Respir. J. 1988, 1, 645-650. [PubMed]

139. Drost, E.; Lannan, S.; Bridgeman, M.M.; Brown, D.; Selby, C.; Donaldson, K.; MacNee, W. Lack of effect of $\mathrm{N}$-acetylcysteine on the release of oxygen radicals from neutrophils and alveolar macrophages. Eur. Respir. J. 1991, 496, 723-729.

140. Jankowska, R.; Passowicz-Muszyńska, E.; Medrala, W.; Banaś, T.; Marcinkowska, A. The influence of n-acetylcysteine on chemiluminescence of granulocytes in peripheral blood of patients with chronic bronchitis. Pneumonol. Alergol. Pol. 1993, 61, 586-591. [PubMed] 
141. Sadowska, A.M.; Van Overveld, F.J.; Gorecka, D.; Zdral, A.; Filewska, M.; Demkow, U.A.; Luyten, C.; Saenen, E.; Zielinski, J.; De Backer, W.A. The interrelationship between markers of inflammation and oxidative stress in chronic obstructive pulmonary disease: Modulation by inhaled steroids and antioxidant. Respir. Med. 2005, 99, 241-249. [CrossRef] [PubMed]

142. Laleu, B.; Gaggini, F.; Orchard, M.; Fioraso-Cartier, L.; Cagnon, L.; Houngninou-Molango, S.; Gradia, A.; Duboux, G.; Merlot, C.; Heitz, F.; et al. First in class, potent and orally bioavailable NADPH oxidase isoform 4 (Nox4) inhibitors for the treatment of idiopathic pulmonary fibrosis. J. Med. Chem. 2010, 53, 7715-7730. [CrossRef] [PubMed]

(C) 2017 by the authors. Licensee MDPI, Basel, Switzerland. This article is an open access article distributed under the terms and conditions of the Creative Commons Attribution (CC BY) license (http://creativecommons.org/licenses/by/4.0/). 